\title{
Use of Medical and Mental Health Care by World War II Survivors in The Netherlands
}

\author{
Inge Bramsen ${ }^{1,2}$ and Henk M. van der Ploeg ${ }^{1}$
}

This study examined the mental and medical health care utilization of World War II (WW II) survivors and the characteristics of survivors seeking professional health care. Forty seven years after the end of WW II, a random sample of 4,057 Dutch WW II survivors answered a four-page questionnaire; 1,461 persons subsequently answered an extensive follow-up questionnaire. Twenty-two percent had sought some form of health care for war-related complaints at some time since WW II. Most consultations were made in the 1940s. More consultations were made to general practioners or to medical specialists as opposed to mental health specialists. Although the level of posttraumatic stress disorder (PTSD) symptoms was most important for discriminating between help-seeking and non-help-seeking respondents, 59\% of the highly-exposed respondents with PTSD had not sought professional help in the years 1990-1992. The results show the importance of primary health care in recognizing PTSD symptoms and referring survivors to the appropriate professional helper.

KEY WORDS: World War Il survivors; health care utilization; posttraumatic stress disorder.

Most studies looking at the psychological aftereffects of war focus on populations seeking treatment or financial compensation. However, if we are to understand the dynamic process of adaptation to traumatic stress and the role that health care professionals might have in alleviating symptoms of posttraumatic stress, those who do not seek mental, medical or financial help must also be heard.

A number of studies have shown that many survivors do not seek professional help or financial compensation. The Eitinger and Ström study of Norwegian concentration camp survivors (1973) noted that, in spite of heightened morbidity rates, only $23 \%$ had applied for and received pensions. Of the survivors attending a national gathering for Holocaust survivors, $77 \%$ had received no psychological

\footnotetext{
${ }^{1}$ Vrije Universiteit Amsterdam, Van der Boechorststraat 7, 1081 BT Amsterdam, The Netherlands.

${ }^{2}$ To whom correspondence should be addressed.
} 
counselling, though $92 \%$ reported that the Holocaust experience had negatively affected their well-being (Kahana, Harel, \& Kahana, 1988). In the National Vietnam Veterans Readjustment Study (NVVRS; Kulka et al., 1990), 86\% of the veterans exposed to high war zone stress did not currently receive mental health care services while 59\% had never applied for these services. These percentages were $78 \%$ and $38 \%$, respectively, for veterans with a current posttraumatic stress disorder (PTSD) diagnosis. Among survivors of urban violence, $79 \%$ had not sought help from mental health care institutions (Van der Ploeg et al., 1985).

This implies that many individuals who have been exposed to war and to other violence are not seen by health care professionals. An important question is how these individuals have adapted. If they did well without professional help, then we might learn from their ways of coping. If, on the other hand, they did not adapt well, this would raise the question why they did not seek support from health care professionals. Knowledge about motives for (not) seeking professional help may enable policy makers and health care professionals to improve the fit between the needs of survivors of war and other violence and the health care organization.

The present study was conducted among a large random community sample of people who experienced World War II (WW II) to find out what proportion of the Dutch WW II survivors sought medical or mental help and what the characteristics of these help-seeking survivors are as compared to non-help-seeking survivors. The majority of these survivors experienced the German occupation of the Netherlands (1940-1945). Others experienced the Japanese occupation of the Dutch East Indies (1942-1945) and the subsequent violent Indonesian independence struggle (1945-1950).

This study addressed the following research questions:

1. How many respondents report that they have contacted mental or medical health care professionals for complaints they attribute to the war? And if they did so, what sort of professional(s) did they consult, when, and how often?

2. What are the characteristics of WW II survivors who received mental or medical health care in the period 1990-1992 for complaints attributed to the war? The expectation was that seeking mental or medical help would be associated with a higher amount of wartime stress, poorer mental and physical health, more recent life events, and less social support (Kulka et al., 1990; Phillips \& Murrell, 1994).

\section{Method}

\section{Research Participants}

In 1992, a 5\% sample of persons with birth years $1920-1929(N=10,622)$ was randomly selected from the municipal population registers of nine Dutch cities (with 85,000-700,000 inhabitants). The age range chosen met two criteria: 
it included (1) people who experienced World War II (1940-1945) as adolescents or young adults, and (2) a large sector of Dutch military veterans.

\section{Procedure}

All participants received a four-page postal questionnaire with a cover letter explaining the purpose of the study and a stamped addressed return envelope. Respondents who agreed to participate in the follow-up were asked to fill in their name and address, thereby explicitly giving informed consent. They received an extensive second-phase questionnaire with a cover letter and a stamped addressed return envelope. Respondents could apply for a report of the results. To increase the response in the second phase, participants were offered a gift voucher of ten Dutch guilders (approximately \$6 U.S.). Adequate arrangements were made to provide for support and after-care (Bramsen, 1995).

\section{Instruments}

First-phase questionnaire. We asked whether participants had personally experienced 19 war events. On the basis of these items, five categories were defined: (1) "Civilians exposed" (civilians who experienced bombardments for instance); (2) "Persecuted in Europe" (survivors of German concentration camps and Jewish people who survived the war in hiding); (3) "Persecuted in Asia" (survivors of Japanese camps and/or persecution by Indonesian nationalists); (4) "Resistance participants"; and (5) "Military veterans." In addition, a "no exposure" and a "multiple exposure" group were differentiated.

Nine additional events based on the A Criterion for PTSD according to the DSM-III-R (American Psychiatric Association [APA], 1987) measured the degree of exposure to violence. For instance: "had been seriously wounded" or "death of family member(s)." The sum of these nine items was used as an indicator of stressor intensity.

Participants were asked whether they had been in contact with any of seven types of professional health care workers for problems related to their wartime experiences or as the consequences of these experiences (for instance, a general practitioner or psychiatrist). If they said "yes," they could indicate whether they had had this contact in one or more of six time periods, starting with "1940-1949" up to "1990 until now." The same questions were repeated for admission to eight institutions (for instance, a general hospital or psychiatric clinic).

Age, gender, marital status, and level of education also were assessed.

The second-phase questionnaire. The Self-Rating Inventory for PTSD (SRIP; Hovens et al., 1994) was used. The SRIP was designed to ask for symptoms independent of the trauma. The test-retest reliability and the internal consistency were found to be high (.90 or higher), and the validity in terms of correlations with 
several other PTSD scales was satisfactory. The sensitivity and specificity was found to be excellent. Sumscores were derived for Intrusion (five items), Avoidance (nine items), Hyperarousal (eight items), and PTSD symptoms (SRIP-DSM). A full diagnosis of PTSD can be determined by means of a cut-off score of 53 or more on the SRIP-DSM (Hovens et al., 1994). Cronbach's alphas for this study sample for the scales of Intrusion, Avoidance, Hyperarousal, and the total scale were $.80, .82, .90$, and .91 , respectively.

The trait-version of the Dutch validated adaptation of the State-Trait Anxiety Inventory (STAI; 20 items; Van der Ploeg, Defares, \& Spielberger, 1980) was used. Cronbach's alpha for the study sample was .92 .

The Dutch validated adaptation of the trait-version of the Zung Self-rating Depression Scale (SDS; 20 items; Mook, Kleijn, \& Van der Ploeg, 1989) was used. The Cronbach's alpha was 83 .

The trait version of the Dutch validated adaptation of the Spielberger Statetrait Anger Scale (STAS; 10 items; Van der Ploeg, Defares, \& Spielberger, 1982) was used. Cronbach's alpha was 89 .

The somatic complaints scale of the Dutch validated adaptation of the SCL90 (12 items; Arrindell \& Ettema, 1986) measured complaints associated with a generalized feeling of physical malfunctioning.

The Dutch validated adaptation of the Social Support Questionnaire (SSQ; 17 items; Tempelaar, De Haes, Van den Heuvel, Van Nieuwenhuijzen, \& Pennink, 1987) measured "supportive social interactions" (e.g., warmth and friendliness) as well as "negative social interactions" (e.g., incomprehension) during the past 7 days. Cronbach's alpha on this study sample were .86 and .82 , respectively.

Two sumscores were prepared: "Life events in social relationships" (e.g., divorce or the breakup of an intimate relationship, problems with children or at work) and "Life events concerning medical illness and bereavement" (e.g., death of spouse, serious bodily harm or illness of yourself or of a close relative or family member).

\section{Participation}

In the first phase, 4,683 questionnaires were returned ( $44 \%) ; 4,057$ questionnaires were fully completed and useful for statistical analysis. The responders were compared to the total sample $(N=10,622)$. They were slightly older $(M=67.6$; $S D=8.1)$ than the total sample $(M=67.3 ; S D=8.3 ; t(14677)=4.55, p<.05)$. Responders were more likely to be men (54\%) as compared to the total sample $\left(44 \% ; \chi^{2}(1, N=14,679)=151.10, p<.05\right)$. In addition, we received 619 incomplete questionnaires with a reason for non-participation. The most frequent reason was thinking that the questionnaire is not applicable because the person had "no important or shocking war experiences" and (thus) "no aftereffects" (45\%). 
Also 39 nonrespondents were telephoned and asked for their main reason for not responding. Among those, the main reason was "indifference" or "not interested" (49\%); $26 \%$ said they experienced 'no shocking or important war experiences'; $13 \%$ mentioned that they did not want to rake up the emotions and wanted to let the past rest; $13 \%$ mentioned circumstances, such as illness etc.

Of the 4,057 respondents in phase one, 2,189 gave their name and address and received a second-phase questionnaire. Of those, 1,461 returned a fully completed questionnaire. This represented $67 \%$ of those to whom phase two questionnaires were sent, $36 \%$ of phase one respondents and $14 \%$ of the 10,622 potential participants to whom phase one letters were sent. Logistic regression analysis on the first phase variables showed that participation in the second phase was predicted by a higher number of war events (partial correlation $(R)=.15, p<.001$; Odds Ratio $(\mathrm{OR})=1.13 ; 95 \%$ Confidence Interval $(\mathrm{CI})=1.10,1.16)$, being male $(R=.02$, $p<.05 ; \mathrm{OR}=1.19, \mathrm{CI}=1.00,1.41)$, and having a higher level of education $(R=.05 ; p<.01)$, i.e., reporting a university degree $(\mathrm{OR}=1.87, \mathrm{CI}=$ $1.26,2.78$, ) or a vocational college degree $(\mathrm{OR}=1.67, \mathrm{CI}=1.22,2.30)$ as opposed to having finished grade school only. No significant differences were found in the use of professional help and in symptoms of PTSD and other psychological and somatic symptoms.

\section{Data Analysis}

Research question one, about the number of WW II survivors who sought professional help, was studied for the total group of respondents that participated in the first phase of the study. Cochran's $Q$ was used to test for significant variations in health care utilization over five decades since the beginning of World War II in 1940. If Cochran's $Q$ was statistically significant, four pairwise comparisons between consecutive decades were carried out using the McNemar Test. The significance level was adjusted using the Bonferroni inequality $(p=.05 / 16=$ .003). The chi-square statistic was computed to test for association between use of professional help and type of war experiences.

The second research question, concerning the characteristics of help-seeking WW II survivors, was restricted to respondents who had participated in the second phase and had been exposed to wartime stress. Logistic regression analysis is the method of choice because the dependent variable, use of professional help in the years 1990-1992, was dichotomous and because some independent variables were continuous and others categorical (Tabachnik \& Fidell, 1989).

Fifteen independent variables were grouped into six sets: (1) demographic variables: gender, marital status, and level of education; (2) stressor intensity; (3) life events since 1980 concerning "social relationships" and "health and bereavement"; (4) social support: "supportive" and "negative social interactions"; 
(5) symptoms of anxiety (STAI), depression (SDS), anger (STAS), and somatic complaints (SCL-90); (6) the PTSD symptoms of intrusion, avoidance, and hyperarousal (SRIP).

These sets were entered into the regression equation in a hierarchical sequence. Within each set, the forward stepwise selection method was used to select variables that made a significant contribution. In this way we examined whether the variables that were selected in one step significantly increased the odds of using professional help after controlling for the effects of variables included in the previous step(s). PTSD symptoms were entered last to control for the effect of all other variables.

\section{Results}

\section{Health Care Utilization}

Table 1 shows that $885(22 \%)$ respondents reported that, at some time since WW II, they consulted at least one health care worker or institution for complaints that they attributed to the war or its aftereffects. A general practitioner was consulted by $12 \%$ of the respondents, and $14 \%$ received specialized medical care. Nine percent reported consultations with mental health care workers. These were most frequently a psychiatrist $(4 \%)$, a clergyman $(3 \%)$, or a psychologist/psychotherapist (2\%)

Table 1. Health Care Utilization Due to the War and/or Its Aftereffects During Five Postwar Decades and the Years $1990-92(N=4,057)$

\begin{tabular}{|c|c|c|c|c|c|c|c|c|}
\hline $\begin{array}{c}\text { Type of } \\
\text { Health Care }\end{array}$ & $\begin{array}{l}\text { Total } \\
n(\%)\end{array}$ & $\begin{array}{c}1940-49 \\
n(\%)\end{array}$ & $\begin{array}{c}1950-59 \\
n(\%)\end{array}$ & $\begin{array}{c}1960-69 \\
n(\%)\end{array}$ & $\begin{array}{c}1970-79 \\
n(\%)\end{array}$ & $\begin{array}{c}1980-89 \\
n(\%)\end{array}$ & $\begin{array}{c}1990-92 \\
n(\%)\end{array}$ & $\begin{array}{c}\text { McNemar's } \\
\text { Test }\end{array}$ \\
\hline $\begin{array}{l}\text { Total } \\
\text { health care }\end{array}$ & $885(22)$ & $563(14)$ & $208(5)$ & $153(4)$ & $187(5)$ & $198(5)$ & $166(4)$ & $1,2,3$ \\
\hline $\begin{array}{l}\text { General } \\
\text { practitioner* }\end{array}$ & $498(12)$ & $264(7)$ & $108(3)$ & $94(2)$ & $108(3)$ & $110(3)$ & $104(3)$ & 1 \\
\hline $\begin{array}{l}\text { Medical } \\
\text { specialist* }\end{array}$ & $575(14)$ & $360(9)$ & $117(3)$ & $83(2)$ & $94(2)$ & $100(2)$ & $81(2)$ & 1,2 \\
\hline $\begin{array}{l}\text { Mental } \\
\text { health care* }\end{array}$ & $334(9)$ & $97(2)$ & $60(1)$ & $53(1)$ & $76(2)$ & $89(2)$ & $59(1)$ & 1,3 \\
\hline
\end{tabular}

Nore. Medical specialist $=$ other medical specialist than psychiatrist and treatment in a general hospital, military hospital, sanatorium, rehabilitation center or nursing home. Mental health care = psychiatrist, social worker, psychologist/psychotherapist, clergyman, psychiatric clinic, convalescent home.

"Four pairwise comparisons between consecutive decades were carried out. Because the last period (1990-1992) refers to three years, no pairwise comparisons were made between 1980 and 1989 and 1990 and 1992. Statistically significant differences $(p<.003)$ are designated by numbers $(1=1940$. 1949 versus $1950-1959,2=1950-1959$ versus $1960-1969,3=1960-1969$ versus $1970-1979$, and $4=1970-1979$ versus $1980-1989$ ).

$* p<.001$. 
Table 2. Health Care Utilization 1940-1992 due to the War or its Aftereffects According to War Exposure

\begin{tabular}{|c|c|c|c|c|c|c|c|}
\hline $\begin{array}{l}\text { Type of } \\
\text { Health Care }\end{array}$ & $\begin{array}{c}\text { Nonexposed } \\
(n=561) \\
n(\%)\end{array}$ & $\begin{array}{c}\text { Civilians } \\
\text { Exposed } \\
(n=2321) \\
n(\%)\end{array}$ & $\begin{array}{c}\text { Resistance } \\
\text { Participants } \\
\begin{array}{c}(n=384) \\
n(\%)\end{array}\end{array}$ & $\begin{array}{c}\text { Military } \\
\text { Veterans } \\
(n=481) \\
n(\%)\end{array}$ & $\begin{array}{c}\text { Persecution } \\
\text { in Asia } \\
(n=74) \\
n(\%)\end{array}$ & $\begin{array}{c}\text { Multiple } \\
\text { Exposed } \\
(n=203) \\
n(\%)\end{array}$ & $\begin{array}{c}\text { Persecution } \\
\text { in Europe } \\
(n=33) \\
n(\%)\end{array}$ \\
\hline $\begin{array}{l}\text { Total } \\
\text { health care }\end{array}$ & $39(7)$ & $422(18)$ & $108(28)$ & $158(33)$ & $33(45)$ & $105(52)$ & $20(61)$ \\
\hline $\begin{array}{l}\text { General } \\
\text { practitioner* }\end{array}$ & $18(3)$ & $262(11)$ & $64(17)$ & $60(13)$ & 23 & $55(27)$ & $16(49)$ \\
\hline $\begin{array}{l}\text { Medical } \\
\text { specialist* }\end{array}$ & $24(4)$ & $262(11)$ & $56(15)$ & $133(28)$ & $18(24)$ & $75(37)$ & $7(21)$ \\
\hline $\begin{array}{l}\text { Mental } \\
\text { health care }\end{array}$ & $10(2)$ & $149(6)$ & $54(14)$ & $53(11)$ & $9(12)$ & $46(23)$ & $13(39)$ \\
\hline
\end{tabular}

Note. Medical specialist = other medical specialist than psychiatrist and treatment in a general hospital, military hospital, sanatorium, rehabilitation center or nursing home. Mental health care = psychiatrist, social worker, psychologist/psychotherapist, clergyman, psychiatric clinic, convalescent home.

$\cdot p<.001$.

The majority of all consultations (14\%) took place during the war or immediately afterwards, in the 1940s. Regardless of the type of health care professional visited, the use of health care decreased until 1969. Then, a small but not statistically significant increase occurred between 1960 and 1969 and 1970 and 1979. The last column in Table 1 shows that in the 3 years preceding the study (1990-1992), $4 \%$ of all respondents used some form of health care.

The seven war exposure groups were significantly different in the likelihood of consultation with general practitioners (see Table $2 ; \chi^{2}(6, N=4,057$ ) $=$ $157.70, p<.001)$, with medical specialists $\left(\chi^{2}(6, N=4,057)=227.07, p<\right.$ $.001)$, and with mental health care professionals $\left(\chi^{2}(6, N=4,057)=163.07\right.$, $p<.001)$ and in the total use of health care $\left(\chi^{2}(6, N=4,057)=292.79, p<\right.$ .001 ). The percentages reporting use of professional help varied from $18 \%$ among the "Civilians exposed" to $61 \%$ among the "Persecuted in Europe" groups. Although the percentage seeking help is lowest among the "Civilians exposed," they are in absolute numbers the largest group.

These figures also show that a considerable part of WW II survivors did not consult professional helpers. The percentages of those who never used professional health care varied from $39 \%$ of the "Persecuted in Europe" to $82 \%$ among highly exposed "Civilians."

\section{Characteristics of WW II Survivors Seeking Medical or Mental Health Care}

To study the characteristics of help-seeking survivors, we selected those second-phase respondents who had been exposed to severe wartime stress during 
WW II and/or the Indonesian conflict. We included all "Persecuted in Europe" $(n=21)$, "Persecuted in Asia" $(n=34)$, and "Multiple exposed" $(n=93)$ who participated in the second phase. Within the categories "Military veterans," "Resistance participants," and "Civilians exposed" the second-phase respondents who had reported at least eight war events ( $n=82, n=68$, and $n=157$, respectively) were selected.

In a hierarchical logistic regression analysis, we examined whether the use of professional help in the years 1990-1992 $(n=54 ; 12 \%)$ for complaints that were attributed to WW II could be predicted by 15 independent variables. The intercorrelations between all variables are shown in the appendix. In six steps the variables that made a significant contribution were selected (see Data Analysis). Table 3 shows the results.

The model chi-square of the final model was significant $(p<.001)$, indicating that, overall, the coefficients of the model were different from zero. Five ORs were significantly different from unity showing that being divorced, having a junior high school level of education (as opposed to "vocational college/university"), having experienced more Criterion A events, and reporting more symptoms of depression and intrusion were associated with use of professional help in the years 1990-1992.

Although "life events in social relationships" and "negative social interactions" were selected and entered into the regression equation in steps 3 and 4 , they ceased to be significant after symptoms of depression and intrusion were entered into the equation. This means that the association of these variables with the use of professional help was fully explained by symptoms of depression and intrusion. After symptoms of intrusion were entered into the regression equation, symptoms of avoidance and hyperarousal had no significant contribution to make. This is due to the high intercorrelations between these variables (see the Appendix).

The final model was able to correctly classify $24 \%$ of the help-seeking respondents $(n=13)$, but at the cost of the false classification of $2 \%(n=8)$ of the non-helpseeking respondents as helpseekers. Overall, $89 \%$ of the respondents were correctly classified. Table 3 shows that during the first three steps of the analysis, the percentage correctly classified helpseeking respondents increased slightly, from 0 to $2 \%$. The inclusion of "negative social interactions" increased this percentage substantially to $11 \%$. However, the contribution of this variable was explained fully by the variables that were entered in the next two steps. By including intrusion in the last step, the percentage of correctly classified help-seeking respondents almost doubled from $13 \%$ to $24 \%$.

$T$-tests were computed to determine whether the variables that were not entered into the regression equation were associated with use of professional help or had no relationship at all. It appeared that those seeking help in the years 1990-1992 had a significantly higher mean score on "anxiety" $(t(453)=5.78$, 


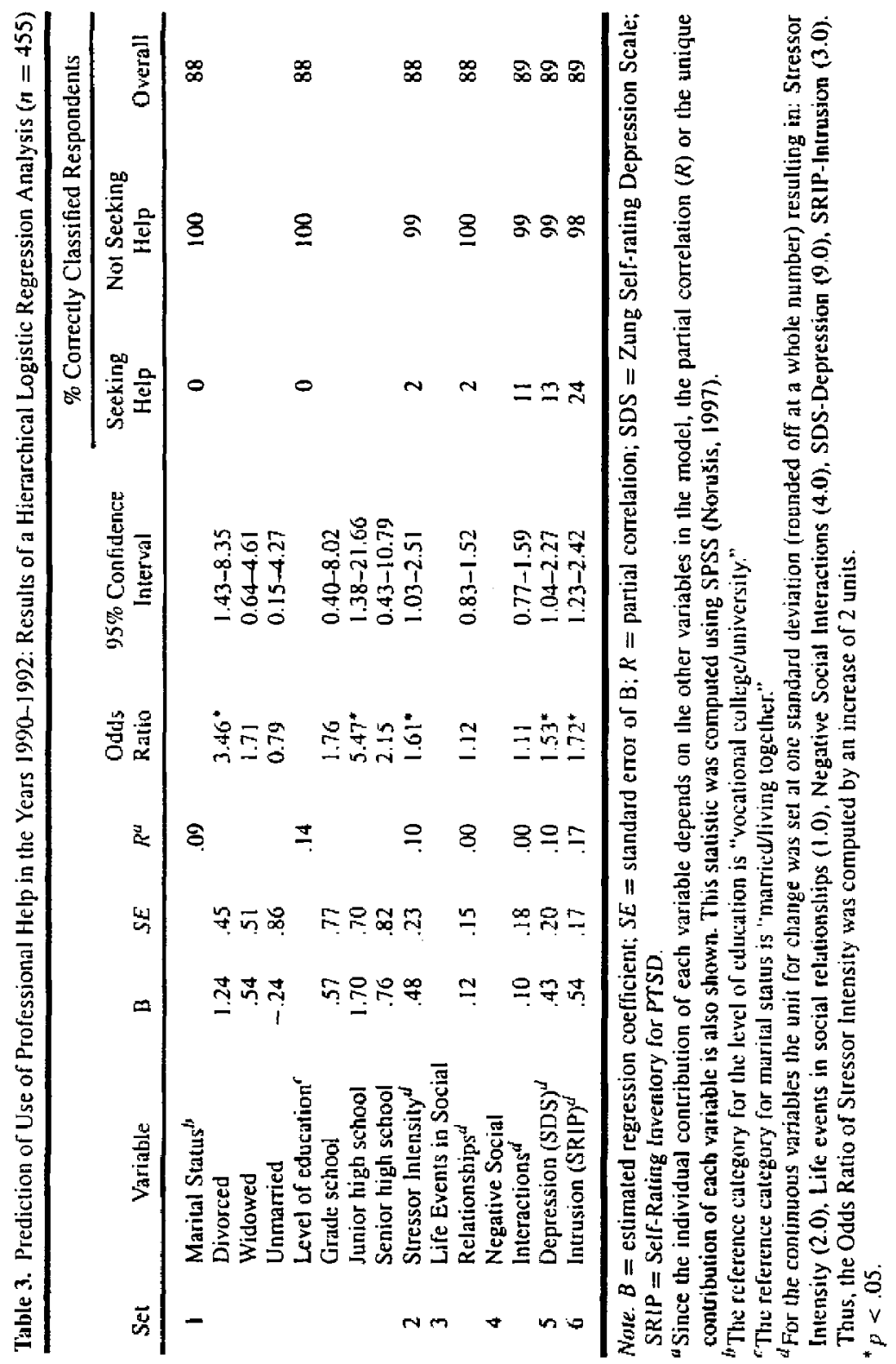


$p<.001)$, "anger" $(t(453)=2.19, p<.001)$, "somatic complaints" $(t(453)=$ $5.74, p<.001)$, "avoidance" $(t(453)=5.91, p<.001)$, and "hyperarousal" $(t(453)=6.57, p<.001)$. Those seeking help had a significantly lower mean score on "supportive social interactions" $(t(453)=2.17, p<.05)$. There were no significant differences in the mean number of "life events concerning medical illness and bereavement" nor in gender.

\section{Health Care Utilization and PTSD}

Since PTSD symptoms were significantly correlated with health care utilization in 1990-1992, this relationship was examined in more detail. Table 4 shows that of the 34 highly exposed respondents with PTSD according to the SRIP, $41 \%$ had contacted at least one health care professional in the years 1990-1992, and $24 \%$ had contacted a mental health care professional, i.e., they had visited a psychiatrist, a social worker, a psychologist, a psychotherapist, or a clergyman or they had stayed in a psychiatric clinic or a convalescent home for problems that they attributed to the war or its aftereffects.

The figures in Table 4 also show that, in the three years preceding the study (1990-1992), 76\% of the highly exposed respondents with a PTSD diagnosis had not seen a mental health care professional and $59 \%$ had not seen any health care professional at all. Looking at the whole period since WW II (1940-1992), 50\%

Table 4. Health Care Utilization Due to the War and/or its Aftereffects Among 34 Highly Exposed Respondents with a PTSD Diagnosis

\begin{tabular}{lc}
\hline Health Care Utilization & $\begin{array}{c}\text { Highly Exposed Respondents } \\
\text { with a PTSD Diagnosis } \\
n=34\end{array}$ \\
\hline In the years 1990-1992 & \\
Total health care & $41 \%$ \\
General practitioner & $29 \%$ \\
Medical specialist & $21 \%$ \\
Mental health care & $24 \%$ \\
Since WW Il (1940-1992) & \\
Total health care & $79 \%$ \\
General practitioner & $62 \%$ \\
Medical specialist & $65 \%$ \\
Mental health care & $50 \%$ \\
\hline
\end{tabular}

Note. Medical specialist $=$ other medical specialist than psychiatrist and treatment in a general hospital, military hospital, sanatorium, rehabilitation center or nursing home. Mental health care $=$ psychiatrist, social worker, psychologist/psychotherapist, clergyman, psychiatric clinic, convalescent home. 
reported no visits to mental health care professionals and $21 \%$ reported no health care consultations at all.

\section{Discussion}

We examined the health care utilization of a large random community sample of Dutch survivors of World War II. Only $22 \%$ of all respondents had consulted at least one health care worker for complaints that they attributed to the war. The majority of these consultations took place in the 1940s. General practitioners were most frequently consulted. Help-seeking survivors were characterized by a higher level of symptoms of intrusion and depression, a higher number of reported war events, a lower level of education, and being divorced.

Three possible limitations of the study deserve mention. First, the respondents in the study are a select group of all WW II survivors because they survived until the present time. Healthy persons with relatively few adaptation problems may be overrepresented, and this may have resulted in lower figures for health care utilization. Also, differential death rates between the exposure groups may have affected the findings. Second, we had to rely on retrospective self-reports of war experiences and contacts with health care professionals. We reasoned that exposure to shocking war events would be a salient event in the memory of the survivor, but that exact details of the event and of possible health care contacts (time, place, frequency) might be subject to distortion. Therefore, we did not ask for exact dates or frequencies of war events or health care contacts, but only whether or not the participants personally experienced the events or had sought the contact. This idea is supported by two recent studies (Henry, Moffit, Caspi, Langley, \& Silva, 1994; Wagenaar \& Groeneweg, 1990).

The third limitation is that due to the relatively high nonparticipation rate, the study sample might not be representative of the Dutch population with birth years 1920-1929. We hypothesized that some survivors might not respond to avoid reliving unpleasant emotions. Therefore, an analysis was made of (1) the reasons given for nonparticipation and (2) characteristics of nonparticipants in the second phase. The most frequently named reason for nonparticipation was that the person "did not experience much." In addition, exposure to shocking war events was the main variable that discriminated participants in the second phase from nonparticipants, while the level of PTSD symptoms made no significant contribution. The higher response of people who had experienced shocking war events may have led to an overestimation of the health care utilization in the sample as a whole. However, the health care utilization in relation to exposure is not expected to be influenced by such a response effect.

Offsetting the limitations mentioned above are several strengths. The first strength of this study was the random community sample. In contrast to many 
other studies, the sample was not limited to WW Il survivors seeking help or applying for financial compensation. The study design has the additional advantage that it enables a comparison not only between different groups of survivors, but also between survivors who had been exposed to shocking war events and a control group of nonexposed participants of the same age and background. Wherever possible we used Dutch adaptations of internationally well-known and frequently used questionnaires. A final strength of the study is the sample size, including sufficiently large numbers of helpseeking and non-help-seeking survivors to permit reliable conclusions.

Health Care Utilization by WW II Survivors over Time: 1940-1992

Most consultations for war-related health problems were made during and immediately following WW II in the 1940s. During the following 2 decades, the percentages seeking health care decreased significantly. In the 1970 s a small but not significant increase was observed.

Meaningful interpretation of these findings concerning health care utilization for war-related health problems during the years 1940-1992 requires some knowledge of the Dutch health care system and of its developments over time. Since WW II, the health care system in the Netherlands has been financed by a combination of social and private insurance so that the whole Dutch population is eligible for almost all forms of health care. Although no fundamental changes in the financial system have occurred, health care itself has changed enormously. In the years 1960-1980, total expenditures on health care have significantly grown (De Folter, 1997). Advancements in medical knowledge and technology have led to a large increase in specialized medical care (De Melker, 1997). The finding of a small increase in health care use for war-related health problems between the $1960 \mathrm{~s}$ and the 1970s must be viewed in the context of this general trend of expansion.

Some have argued that it is possible that during the process of aging, delayed symptoms of PTSD may occur and that this may lead to an increased need for professional help. The reported results do not lend support to this idea.

However, one reservation must be made. The division of the 53 years since the beginning of WW II into 5 decades and one period of three years (1990-1992) does not allow for a conclusion about the last 3 years. So we cannot rule out the possibility that an increase occurred from 1990 onward. Also, whether the use of help will remain stable in the 1990s is something that remains to be seen. In an ongoing follow-up study, we are studying this issue (Bramsen \& Van der Ploeg, 1998a).

\section{Mental Health Care and the Role of the Family Doctor}

The health care professional most frequently consulted was the general practitioner or family doctor. This is not surprising, since in the Dutch health care 
system, specialized and hospital care can only be provided on referral of the family doctor (De Melker, 1997). This finding is also consistent with the observation that many mental health problems are handled in the general medical sector (see, e.g., Commander et al., 1997; Goldberg \& Huxley, 1992). This means that the family doctor has an important function in determining whether an individual needs specialized care and what sort of care this should be.

Although PTSD symptoms were most strongly correlated with health care utilization for war-related complaints, respondents reported more consultations with medical specialists than with mental health care professionals. Therefore, it seems likely that some survivors with PTSD symptoms received help from medical specialists instead of mental health care specialists.

This is in line with Philips \& Murrell's (1994) report that older people seemed reluctant to seek help from mental health care specialists and found it easier to consult their physician. In our study, too, the general practitioner was the health care professional most frequently consulted. Maybe these survivors were referred to medical health care specialists because they informed their general practioner only about their somatic complaints (e.g., sleeping problems) and not about their mental complaints. Kirmayer et al. (1993) studied this issue of "somatization" and found that $76 \%$ of 75 patients with a major depression or anxiety disorder made somatic presentations to their family doctor.

In some cases, the family doctor may have recognized the true nature of the symptoms but may have encoutered difficulties in persuading the survivor to seek mental health care. Many Dutch people, especially those of the older generation, are afraid to receive the label "lunatic." They may also have had disappointing experiences in the past. The system of mental health care has changed tremendously. Following WW II, there was little knowledge of mental health problems. The mental health care system was focused on offering an asylum and custodial care for people with severe psychiatric problems (Schnabel, 1997). Specialized care for war victims was developed in the 1970s. Thus, the family doctor has an important role not only in recognizing PTSD and referring the survivor to the appropriate professional helper, but also in persuading the survivor to follow his or her advice.

\section{Health Care Utilization among Different Groups of Survivors}

The relatively high use, and need, for health care among the "Persecuted in Europe," the "Multiple exposed" and "Persecuted in Asia" might be due to the fact that they experienced a sequence of stressful events. The "Persecuted in Europe" not only had to endure many hardships during the war. Afterwards they were confronted with the loss of many, if not all, of their family members. The "Persecuted in Asia" first experienced the occupation of the Dutch East Indies by the Japanese followed by the independence struggle of the Indonesians immediately afterwards 
that forced them to migrate to the Netherlands. The "Multiple exposed" includes a large group of respondents $(n=133)$ who participated in resistance work during WW II and then, immediately afterwards took part in military operations in the former Dutch East Indies in the years 1945-1950. Other Multiple exposed respondents $(n=39)$ first experienced the occupation of the Dutch East Indies by the Japanese and then engaged in military operations in the years 1945-1950. The relatively high use of health care among these three groups is also in line with the finding described elsewhere (Bramsen \& Van der Ploeg, 1998b) that these survivor groups had the highest rates of PTSD.

The "Civilians exposed" reported the smallest use and need for health care. However, it is important to note that in absolute numbers they make up the largest part of all helpseeking respondents. Among them are many men who were forced to work in Germany. They generally lived under difficult circumstances: small overpopulated barracks, bad hygienic conditions, lice, and malnutrition. Many worked near strategic targets and had, therefore, a high chance of being hit in the intensive allied bombardments. Other "Civilians exposed" experienced bombardments in The Netherlands or were exposed to violence during the battles that took place in populated areas.

\section{Characteristics of WW II Survivors Seeking Help in 1990-1992}

Seeking professional help was most strongly correlated with PTSD symptoms. In addition, symptoms of depression appeared to be important. Studies of Vietnam veterans (Kulka et al., 1990) and survivors of urban violence (Van der Ploeg et al., 1985) have also shown that people with more serious complaints are more likely to seek help than those with minor complaints or no complaints at all.

Respondents reporting more stressful war events were more likely to have resorted to professional health care in the years 1990-1992. Kulka et al. (1990) also found a relationship between exposure and use of help. One explanation is that higher exposure leads to a higher risk for PTSD and therefore, to a higher use of professional health care. However, the logistic regression analysis showed that the contribution of stressor intensity to the "prediction" of health care utilization remained statistically significant after controlling for symptoms of depression and PTSD. Thus, part of the correlation between wartime stress and health care utilization was not explained by the variables under study.

The relationships between "life events in social relationships," "negative social interactions," and health care utilization was fully explained by symptoms of depression and intrusion. This finding suggests that symptoms such as depression and intrusion may lead to difficulties in social relationships. The significant contribution of "being divorced" may also be seen in this light. These findings are in line with studies that found that PTSD symptoms of military veterans imposed 
many difficulties on the relationship with their spouses (Bramsen, Klaarenbeek \& Van der Ploeg, 1995; Kulka et al., 1990).

The finding that a lower level of education was associated with health care utilization is in line with other studies (Mackenbach, 1993; Van der Ploeg et al., 1985). The percentage of explained variance due to this variable was, however, low.

\section{Explanations for Not Seeking Help}

Current use of help was relatively low among people with current PTSD. In the 3 years preceding the study, $41 \%$ had consulted a medical or mental health care professional, and only $24 \%$ had contacted a mental health care professional. Partly, those who did not seek help in the years 1990-1992 had sought help at an earlier point in time. Perhaps these survivors have accepted their symptoms or have found a way of dealing with them. It is also possible that they believe that they cannot be helped. Some respondents related that they had tried to find help, but had been disappointed, or even hurt, by the reactions of their general practioner or psychiatrist. Their symptoms were not taken seriously; the doctor showed no understanding, or did not believe that their symptoms were related to the war. As a result they did not receive the help they needed and developed a mistrust of the helping professions which lasted right up to the present.

We found that half of the highly exposed respondents with PTSD had never consulted a mental health care professional and nearly $40 \%$ had never seen their family doctor for war-related health problems. Thus, it is important to know more about factors that determine whether or not a person with PTSD symptoms resorts to professional health care.

A possible explanation is that reluctance to seek help is a consequence of the avoidance symptoms of PTSD. In a recent study, school staff caught up in a shooting incident and who were reluctant to use mental health services reported more avoidance symptoms than those who did use help (Schwartz \& Kowalski, 1992). This phenomenon was also observed among employees exposed to an industrial disaster (Weisaeth, 1989). However, these findings were contradicted by a number of other studies which found that PTSD symptoms, including the avoidance symptoms, were associated with an increased use of health care services. (Kulka et al., 1990; Van der Ploeg et al., 1985; Solomon, 1993). In our study, avoidance symptoms were also associated with an increased use of health care services. In addition, when we controlled for the shared variance with other PTSD symptoms, we found no evidence for a negative influence of avoidance symptoms on health care use.

There must, then, be other reasons and motives that determine why an individual with PTSD symptoms refrains from seeking professional help. Inspection of the written narratives in the questionnaires revealed that a frequently reported motive for not requesting professional help was "wanting to solve my own problems 
independently." This motive was also found in other studies (Kulka et al., 1990; Van der Ploeg et al., 1985). Undoubtedly, this attitude of self-reliance has been a successful coping strategy for many WW II survivors. On the other hand, some people may have underestimated the seriousness of their symptoms or overestimated their own capacities for coping with them. Their so-called "identification threshold" (Solomon, 1993) may have been too high, and they may have failed to recognize that they required help. Throughout the years some may have become used to their symptoms.

An additional factor which may have been relevant for our study population is that "talking about things that bother you" was not a characteristic of their generation. After the war, most people thought it best to forget the past and to look toward the future. This resulted in a so-called "conspiracy of silence" (Danieli, 1981) that may have made it difficult not only to talk to one another about the war, but also to talk to doctors and other health care professionals.

Further research is necessary to find out how survivors of extreme violence with mental health problems can be reached by the appropriate professional helper. Patient characteristics as well as characteristics of the health care system and its professionals should be included in such a study. 


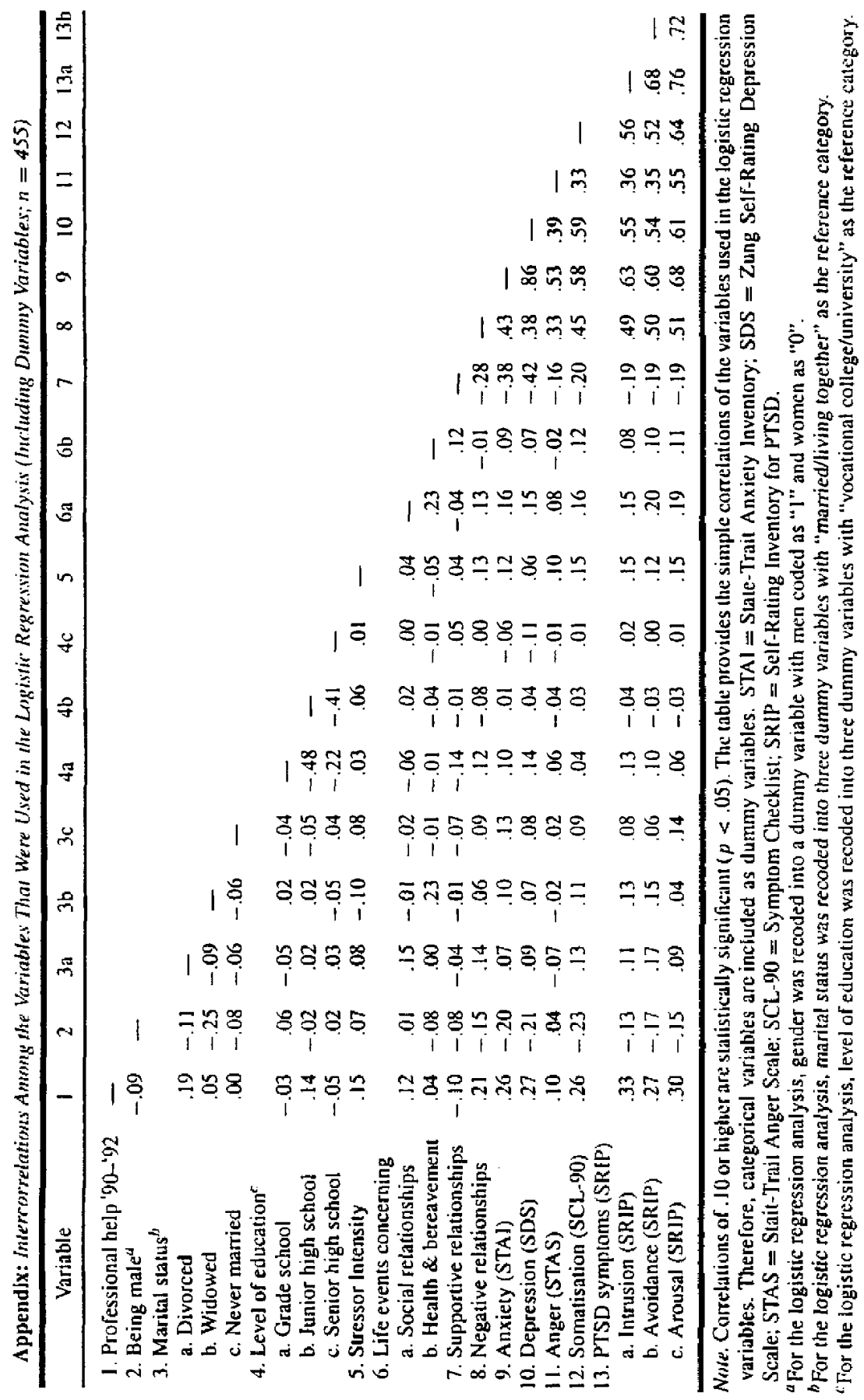




\section{References}

American Psychiatric Association (1987). Diagnostic and statistical manual of mental disorders (3rd ed., rev.) (DSM-III-R). Washington, DC: Author.

Arrindell, W. A., \& Ettema, J. H. M. (1986). SCL-90. Handleiding bij een multidimensionele psychopathologie-indicator. Lisse, The Netherlands: Swets \& Zeitlinger.

Bramsen, 1. (1995). The long-term psychological adjustment of World War II survivors in The Netherlands. Thesis. Delft, The Netherlands: Eburon.

Bramsen, I., Klaarenbeek. M. T. A., \& Van der Ploeg, H. M. (1995). Leven met militaire oorlogsgetroffenen. De partners van BNMO-leden in beeld gebracht [Living with military veterans. A portrait of spouses of BNMO-members.] In H. M. van der Ploeg \& J. M. P. Weerts (Eds.), Veteranen in Nederland. Onderzoek naar de gevolgen van oorlogservaringen. Tweede Wereldoorlog. politionele acties, Korea (pp. 147-164). Lisse, The Netherlands: Swets \& Zeitlinger.

Bramsen, I., \& Van der Ploeg, H. M. (1998a). Verwerkingsproblemen naar aanleiding van de Tweede Wereldoorlog: Een longitudinale studie onder ouderen. [Adjustment problems and World War II: A longitudinal study among the aged]. In M. I. Broese van Groenou, D. H. J. Deeg. C. P. M. Knipscheer, \& G. J. Lighthart, (Eds.), VU.Visies op veroudering (pp. 197-198). Amsterdam: Thela Thesis.

Bramsen, I., \& Van der Ploeg, H. M. (1998b). Fifty years later: The long-term psychological adjustment of aging World War II survivors in the Netherlands. Manuscript submitted for publication.

Commander, M. J., Sashi Daran, S. P., Odell, S. M., \& Surtees, P. G. (1997). Access to mental health care in an inner-city health district. I: Pathways into and within specialist psychiatric services. British Journal of Psychiatry, 170, 312-316.

Danieli, Y. (1981). Families of survivors of the Nazi Holocaust. Some short-and long-term effects. In C. D. Spielberger, I. G. Sarason, \& N. Milgram (Eds.). Stress and anriery, Vol. 8. (pp. 405-421). New York: McGraw Hill.

De Folter, R. J. (1997). The services of medical specialists and hospitals. in A. J. P. Schrijvers (Ed.), Health and health care in the Netherlands (pp. 90-100). Utrecht, The Netherlands: De Tijdstroom.

De Melker, R. A. (1997). The family doctor. In A. J. P. Schrijvers (Ed.), Health and health care in the Netherlands (pp. 60-72). Utrecht, The Netherlands: De Tijdstroom.

Eitinger, L., \& Ström, A. (1973). Mortality and morbidity after excessive stress. Oslo, Nonway: Universitetsforlaget.

Goldberg. D., \& Huxley, P. (1992). Common mental disurders. A bio-social model. London: Routledge.

Henry. B.. Moffit. T. E., Caspi, A., Langley, J., \& Silva, P. A. (1994). On the 'remembrance of things past': A longitudinal evaluation of the retrospective method. Psychological Assessmem, 6, 92-101.

Hovens, J. E., Van der Ploeg, H. M., Bramsen, I., Klaarenbeek, M. T. A.. Schreuder, J. N., \& Rivere, V. V. (1994). The development of the self-rating inventory for posttraumatic stress disorder. Acta Psychiatrica Scandinavica, 90,172-183.

Kahana, B., Harel, Z., \& Kahana, E. (1988). Predictors of psychological well-being among survivors of the Holocaust. In J. P. Wilson, Z. Harel, \& B. Kahana (Eds.), Human adaptation to extreme stress, from the Holocaust to Vietnam (pp. 171-192). New York: Plenum Press.

Kirmayer. L. J., Robbins, J. M., Dworkind, M., \& Yaffe, M. J. (1993). Somatization and the recognition of depression and anxiety in primary care. American Journal of Psychiarry, 150, 734-741.

Kulka, R. A., Schlenger, W. E., Fairbank, J. A., Hough, R. L., Jordan, B. K., Marmar, C. R., \& Weiss, D. S. (1990). Trauma and the Vietnam war generation. Report of findings from the National Vietmain Veterans Readjustment Study. New York: Brunner/Mazel.

Mackenbach, J. P. (1993). De CBS-Gezondheidsenquete. Nederlands Tijdschrift voor Geneeskunde, $137,1488-1492$.

Mook, J., Kleijn, W. Chr., \& Van der Ploeg, H. M. (1989). Depressiviteit als dispositie gemeten met de Zungschaal: Interne structuur en relaties met angst, boosheid, coping en sociale steun. Nederlands Tijdschrift voor de Psychologie, 44, 328-340.

Norusis, M. J. (1997). SPSS Professional Statistics 7.5. Chicago: SPSS Inc.

Phillips, M. A., \& Murrell, S. A. (1994). Impact of psychological and physical health, stressful events, and social support on subsequent mental health help seeking among older adults. Joumal of Consulting and Clinical Psychology, 62, 270-275.

Schnabel, P. (1997). The mental health services: More than psychiatry alone. In A. J. P. Schrijvers 
(Ed.). Health and health care in the Netherlands (pp. 119-130). Utrecht, The Netherlands: De Tijdstroom.

Schwartz, E. D., \& Kowalsky, J. M. (1992). Malignant memories. Reluctance to use mental health services after a disaster. Journal of Nervous and Mental Disease, 180, 767-772.

Solomon, Z. (1993). Combat stress reaction. The enduring toll of war. New York: Plenum Press.

Tabachnik, B. G., \& Fidell, L. S. (1989). Using multivariate statistics (2nd ed.). New York: Harper Collins Publishers.

Tempelaar, R., De Haes, J. C. J. M., Van Den Heuvel, W. J. A., Van Nieuwenhuijzen, M. G., \& Pennink, B. J. W. (1987). Een meetinstrument voor positieve en negatieve sociale ervaringen van (kanker-) patiënten. Tijdschrift voor Sociale Gezondheidszorg, 65, 648-653.

Van der Ploeg, H. M., Defares, P. B., \& Spielberger, C. D. (1980). Handleiding bij de Zelfbeoordelings Vragenlijst (ZBV). Een Nederlandstalige bewerking van de Spielberger State-Trait Anxiety Inventory: STAI-DY. Lisse, The Netherlands: Swets \& Zeitlinger.

Van der Ploeg H. M., Defares, P. B., \& Spielberger C. D. (1982). Handleiding bij de Zelf-Analyse Vragenlijsi (ZAV). Een vragenlijst voor het meten van boosheid en woede, als toestand en dispositie. Een Nederlandstalige bewerking van de STAS. Lisse. The Netherlands: Swets \& Zeitlinger.

Van der Ploeg, H. M., Van Buuren, E. T., Wöstmann, M. Hulshof, R. E., Huisman, S. J., Kleijn, W. Chr., \& Stoffels, M. L. (1985). Psychologisch onderzoek naar (het ontbreken van) de hulpvraag van slachtoffers van geweld. Deel 1 . Lisse, The Netherlands: Swets \& Zeitlinger.

Wagenaar, W. A., \& Groeneweg, J. (1990). The memory of concentration camp survivors. Applied Cognitive Psychology, 4, 77-87.

Weisaeth, L. (1989). Importance of high response rates in traumatic stress research. Acta Psychiatrica Scandinavica, 80, 131-137. 